\title{
Improvement of the Concept of the Image of the Enterprise for the Account of Social-Ecological Public Effects
}

\author{
Alla Dergousova $^{1}$ *, Yuriy Elagin ${ }^{1}$, Oksana Chebanova $^{1}$ \\ ${ }^{1}$ Ukrainian State University of Railway Transport \\ 2 *Corresponding author E-mail: dergousova.alla@gmail.com
}

\begin{abstract}
The concept of enterprise image and social responsibility has been studied. It has been proved that in the global civilized business environment, it is necessary to rely on moral and social aspects to achieve competitive advantages and consumer loyalty. It has been identified that the formation of a sustainable image of an enterprise is the readiness of the company to be responsible to society, namely, to care for the environment, the health of consumers, and for observing their consumer and civil rights. It has been found out that the creation of the company's image is also influenced by environmental responsibility of the enterprise. The experience in implementation of social and environmental responsibility at the enterprises of the European Union has been analyzed. The concept of the company's image is improved due to the scientific justification for the need to introduce social and environmental components as weighty factors affecting the corporate strategy. This will make it possible to increase the competitiveness and image of the enterprise, to form a high level of loyalty to the enterprise's products in a consumer's mind.
\end{abstract}

Keywords: Corporate strategy; customer loyalty; development strategy; environmental responsibility; global contract; image of an enterprise; social responsibility.

\section{Introduction}

In modern business conditions, the image of the enterprise is an obligatory component of competitiveness. Without a positive image in the long term, it is impossible to achieve a sustainable competitive position and customer loyalty to the company's brand of the enterprise. The enterprise's image includes many components, but the social aspect - the social responsibility of business - becomes particularly relevant in terms of market globalization. It is social responsibility that shapes public opinion about the enterprise among consumers, partners, competitors and other contact audiences through the open information space.

Currently, there is a document regulating the corporate social responsibility. This is a UN Global Compact that aims to promote social responsibility and support for the issues of economic globalization expressed by business circles. On the site of the Compact, you can see on-line the number of countries and corporations that have already joined the Global Compact [1] these are 9678 companies and 161 countries. Unfortunately, in Ukraine only about 200 enterprises have signed the Global Compact, despite its high efficiency for the creation of the company's image. Thus, unfortunately, there is no systematic support for the corporate social responsibility in Ukraine.

\section{Analysis of Scientific Research and Publications on the Topic of Social Responsibility of Business}

Studies of the issue of corporate social responsibility have been described in the works of many domestic authors. In particular, V.M. Shapoval has focused his attention on insufficient support of social programs and projects of enterprises by government authorities, lack of an open dialogue on the development of appropriate incentives for business, which seeks to implement the principles of social responsibility in its activities [2]. The monograph by A.P. Gogul and I.P. Kudinova [3] has highlighted the issues of the corporate social responsibility as a modern philosophy of behavior and the concept that shapes society. The results of expert surveys of scientists and teachers of Ukraine on the issues of the social responsibility of the individual, society, business and the state have been presented in the work of A.F Novikov, M.E. Deych, A.V. Pankov and others [4]. Theoretical and practical aspects of the development of social responsibility have been reflected in the monograph of A.M. Kolot [5]. Regulatory instruments for referring social responsibility of business to the system of national economy have been systematically developed in the scientific work of I. Tsarik [6]. In the scientific research by T.G. Antoshka, P.V. Krush, Yu. V. Tyuleneva, the social responsibility has been defined as a new civilizational stage in the society and business development of, which makes it possible to find a consensus between the commercial interests of the corporation and the positive expectations of society [7]. The "Corporate Social Responsibility Development" Centre and the Representative Office of the 
Friedrich Ebert Foundation in Ukraine have been actively working on the study and introduction of corporate social responsibility in Ukraine.

However, existing scientific studies do not pay sufficient attention to the impact of social responsibility on the company's image and the need for its inclusion in the corporate strategy of the company's development. Therefore, the survey of this issue needs further study and elaboration.

\section{Study of the Issues and Prospects for the Development of Corporate Social Responsibility}

\subsection{Identifying Current Trends in the Creation of the Image of the Company}

In what way does the company become visible on the market and cause trust and loyalty among consumers? This issue is one of the most important both in the process of the enterprise establishment and throughout its life cycle. It reflects the problem of forming an image and creating a product which is psychologically different from that of other firms. A favorable image should be adequate, original, malleable and targeted. The image adequacy is a correspondence to the real image or specifics of the firm. Originality is a unique difference of an enterprise from similar companies-competitors. Malleability allows the image not to become obsolete, not to go out of fashion, but at the same time to remain unchanged in the minds of buyers. Targeted orientation is an attractive position for a certain target audience, namely, for permanent and potential customers.

Figuratively speaking, the company's image is its "face" in the "mirror of public opinion", that is, the existing view of the target audience about the activities and successes of the company, which has a permanent and dynamic impact on the relationship of the enterprise with its real and potential customers, as well as its competitiveness, financial results and contacts with government agencies.

Imagology was offered by the American economist D. Bolding in 1961. As a special area for studying the environment conducive to business development. Unfortunately, only decades later this area gained recognition in Ukraine. Now it is developing as a science of the formation of multiple images in the public and individual minds. This is about the images of individual leaders of the political and economic spheres of society, as well as images of individual enterprises. This process is vital for the establishment of a highly developed business and political culture in the country. Principles and conditions for the image formation have been demonstrated by Maslow's pyramid - the hierarchy of needs. Everything starts with satisfying the basic needs - physiological (food, water, sleep) and safety needs (security, safety), and moves to the satisfaction of higher social needs - social belonging (family, friendship), esteem and self-actualization needs. Namely, the last need reflects the need to form one's own positive image. Thus, obtaining positive perceptions of the individual by the society and influencing their attitude is regularity in terms of psychology and social development of society. And this can be attached to the need to form an enterprise image.

In the world practice, the creation of the company's image is considered as one of the strategic management objectives, which is deemed no less important than the introduction of new technologies, stabilization of the financial environment, recruitment and expanding sales markets.

The image of the enterprise is an integral perception (understanding and evaluation) of the firm by various groups of the public, which is formed on the basis of the information about various aspects of the enterprise's activities stored in their memory. That is, it is something between the perception that the company wants to create of itself in the society (the company's active actions to form and adequately perceive its "face"), and the perception of the company that exists in society ("reflection" of the company's face in the customer's memory). It is an emotionally colored image of an enterprise, often consciously formed, with clearly defined characteristics and designed to cause a certain psychological effect on specific groups of society.

One of the important components of the company's image is its social responsibility and the creation of a social image in the public eye, which positively influences the further development and formation of the society's loyalty to it [8].

\subsection{Analysis of the Problems of Implementing Social Responsibility in Business Realities}

Broadly speaking, the corporate social responsibility is a common system of values, activities and processes, the purpose of which is to spread a positive image of the company's activities in the economic, environmental and social spheres, both within the enterprise and in the environment. Implementation of socially responsible strategies should focus not only on reducing and preventing negative consequences of activities, but also on achieving economic, environmental and social effects, which can be considered as a basis for increasing the competitiveness of individual companies and the national economy as a whole.

Corporate social responsibility is widespread in Europe. In some countries it is integrated into public policy (Denmark, France, Finland, Sweden), in others - socially responsible practices are the sole responsibility of major companies (Greece, Ireland, Netherlands, Slovenia). In the European Union, the main role of corporate social responsibility is to support the sustainable development of companies, which leads to an improvement in the situation in the labor market, as well as the quality of products and services [9].

Today, the corporate social responsibility is one of the components of corporate strategy. The implementation of the principle of social responsibility is associated with the public legal regulation of funds of commercial organizations, that is, the legal regulation of the distribution of profits should ensure the use of a part of profits of commercial organizations with a view to implementing social functions and co-financing the social issues of society.

The widespread adoption of corporate social responsibility principles into practice dates back to the 1970s of the 20th century. In modern conditions, the governments of all the leading countries attribute the social and economic development to the expansion of social responsibility of commercial organizations. It is this approach - to economic growth through social responsibility as a factor of sustainable development - has laid the foundation for the Lisbon strategy adopted in 2000 as a policy for the socioeconomic development of the European Union [10].

And in the current context of the development of market relations, any organization seeking to take the leading positions and have a significant impact on the processes taking place within the society, should take into account that the majority of leading companies, regardless of the area of activity, form their own corporate social responsibility (CSR) policy. In general, CSR involves the fulfillment by the organizations of social obligations prescribed by their social duty to employees, consumers and society as a whole, as well as the willingness to fully bear corresponding mandatory and discretionary social expenses beyond the limits established by tax, labor, environmental and other legislation, on the basis not of the requirements of the law, but of moral and ethical reasons.

The formation of a positive social image of enterprises is also affected by the so-called environmental responsibility of business.

\subsection{The Results of Studies of Foreign Expertise in the Implementation of Environmental Responsibility in the European Business Practice}

Currently, environmentally and socially responsible business means: business moving beyond the selfish framework of its own economic efficiency and the contribution of resources to the longterm development of the internal and external environment; 
implementation of environmental and social activities, preservation of well-paid jobs, production of quality goods and services, environmental protection, fair business relations in business circles; taking into account changing public expectations with regard not only to their products and increasing profitability, but also their participation in the establishment of the national economy of the country. Unfortunately, these aspects are not decisive for the business strategies of Ukrainian enterprises. In most cases, environmental responsibility is considered as legal and voluntary activities which can slightly increase the firm's competitiveness and reinforce its image, but is all.

Studies have shown that in the current conditions of the global economy development, society suffers from the results of economic activity in the form of climate change, hurricanes, which bring multi-billion losses both to individual countries and the entire world economy.

In 2017, economic losses caused by catastrophes associated with climate change reached a record level of $\$ 320$ billion. Carbon dioxide emissions into the atmosphere increased by $1.4 \%$ up to 32.5 gigatons, which is also a record level. In 2017, the hurricane season in the Caribbean turned out to be the highest economic damage, in South Asia 41 million people were affected by the floods, almost 900,000 people in Africa were forced to leave their homes because of the drought, and the area of sea ice sharply decreased in the Arctic [11].

There is a scientific consensus that global warming with a high probability is explained by human activities and is caused by anthropogenic increase in the carbon dioxide concentration in the Earth's atmosphere, and, as a result, the growth of the greenhouse effect.

Therefore, in many developed countries of the world (Germany, the USA, France) they are turning to pure energy - solar, wind, hydro. Thus, switching away from the use of gas and coal reduces the amount of harmful emissions to the environment.

In Ukraine, this trend is also observed, although at a rather slow rate. Electricity production in the United Power System (UPS) of Ukraine in 2017 increased by $0.4 \%$ (by 596.8 million $\mathrm{kWh}$ ) compared to 2016 - up to 155 billion 414.2 million kWh (Table 1). Nuclear power plants (NPPs) in 2017 increased electricity generation by $5.7 \%$ - up to 85 billion 576.1 million kW-h. In particular, electricity generation at Zaporizhia NPP amounted to 34.5 million $\mathrm{kWh}(+11.2 \%$ by 2016), Southern Ukraine - 17 billion 900.3 million kWh (2.3\%), Rivne - 19.793 billion kWh (+ 13.3\%), Khmelnitsky - 13 billion 382.8 million kWh (-10.6\%).

Thermal power plants (TPPs), as well as combined heat and power plants (CHPP) and cogeneration plants (CP), reduced output by $9.2 \%$ - up to 55 billion 841.3 million $\mathrm{kWh}$. Including, the generating companies of TPPs reduced the generation by $9.9 \%$ up to 44.96 billion $\mathrm{kWh}$, and CHPP and CP - by $6.1 \%$, up to 10 billion 881.3 million $\mathrm{kWh}$. Hydroelectric and pumped storage power plants (HPPs and PSPs) in 2017 increased output by $13.7 \%$ to 10 billion 567.7 million $\mathrm{kWh}$, isolated generating plants - by $1 \%$, to 1 billion 530.9 million $\mathrm{kWh}$.

At the same time, the electricity generation by alternative sources (WPP, SPP, biomass) for 2017 increased by $21.6 \%$ - up to 1 billion 898.1 million $\mathrm{kWh}$.

The share of nuclear power plants in the structure of electric power generation amounted to $55.06 \%$ (in $2016-52.29 \%$ ), TPPs, CHPPs and CPs $-35.93 \%$ (39.72\%), HPPs and PSPs - 6.8\% (6, $01 \%)$, isolated generating plants $-0.99 \%(0.98 \%)$, alternative sources $-1.22 \%(1.01 \%)$.

Electric power production in the UPS of Ukraine in December 2017 decreased by $5.8 \%$ (by 907.8 million $\mathrm{kWh}$ ) compared to the same month in 2016 - up to 14.811 billion kWh.

In addition, thermal energy generation for 2017 decreased by $12.7 \%$ (by 3 million 53.6 thousand Gcal) compared to 2016 - up to 21 million 84.7 thousand Gcal.

In the UPS of Ukraine in 2016, it decreased by $1.8 \%$ (by 2.848 billion $\mathrm{kW}$-h) compared to 2015 - up to 154 billion 817.2 million $\mathrm{kWh}$. Also, NPPs generated 80.950 billion $\mathrm{kWh}(-7.6 \%)$, GC TPPs - 49 billion 902.3 million $\mathrm{kWh}(+1 \%)$, TPPs -6 billion 709.3 million $\mathrm{kWh}(+10.4 \%)$, HPPs and PSPs -9 billion $118.8 \mathrm{mln} \mathrm{kWh}$ $(+33.9 \%)$, utility CHPPs and isolated generating plants -6 bln $576.8 \mathrm{mln} \mathrm{kWh}(+6.5 \%)$, WEC, SES and biomass - up to 1.560 billion $\mathrm{kWh}(-2 \%)$.

Table 1: Structure of electricity production in the UPS of Ukraine for 2016 and 2017

\begin{tabular}{|c|c|c|c|c|c|c|}
\hline $\begin{array}{l}\text { Power } \\
\text { producers }\end{array}$ & $\begin{array}{l}2016 \text {, } \\
\text { million } \\
\mathrm{kWh}\end{array}$ & $\begin{array}{l}2016, \\
\text { share of } \\
\text { total } \\
\text { productio } \\
n, \%\end{array}$ & $\begin{array}{l}2017 \text {, } \\
\text { million } \\
\mathrm{kWh}\end{array}$ & $\begin{array}{l}2017, \\
\text { share of } \\
\text { total } \\
\text { productio } \\
\mathrm{n}, \%\end{array}$ & $\begin{array}{l}\text { change } \\
\text { millio } \\
\mathrm{n} \mathrm{kWh}\end{array}$ & $\begin{array}{l}\text { change } \\
, \%\end{array}$ \\
\hline NPP & $80,950.1$ & 52.3 & $85,576.1$ & 55.1 & $\begin{array}{l}4, \\
626.0\end{array}$ & 5.7 \\
\hline GC TPP & $49,902.3$ & 32.2 & $44,960.0$ & 28.9 & $\begin{array}{l}- \\
4,942 . \\
3\end{array}$ & -9.9 \\
\hline $\begin{array}{l}\text { CHPP } \\
\text { and CP }\end{array}$ & $11,592.1$ & 7.5 & $10,881.3$ & 7.0 & -710.8 & -6.1 \\
\hline HPP & $7,663.7$ & 5.0 & $8,982.5$ & 5.8 & $\begin{array}{l}1,318 . \\
8\end{array}$ & 17.2 \\
\hline $\begin{array}{l}\text { Pumped } \\
\text { storage } \\
\text { plant }\end{array}$ & $1,633.8$ & 1.1 & $1,585.2$ & 1.0 & -48.6 & -3.0 \\
\hline $\begin{array}{l}\text { Isolated } \\
\text { generatin } \\
\text { g plant }\end{array}$ & $1,515.1$ & 1.0 & $1,530.9$ & 1.0 & 15.8 & 1.0 \\
\hline $\begin{array}{l}\text { Alternativ } \\
\text { e sources } \\
\text { (WPP, } \\
\text { SPP, } \\
\text { biomass) }\end{array}$ & $1,560.3$ & 1.0 & $1,898.1$ & 1.2 & 337.8 & 21.6 \\
\hline TOTAL & $\begin{array}{l}154,817 . \\
4\end{array}$ & 100.0 & $\begin{array}{l}155,414 . \\
2\end{array}$ & 100.0 & 596.8 & 0.4 \\
\hline
\end{tabular}

The need to introduce a priority energy saving policy is primarily related to the deficit of own fuel and energy resources, dependence on gas-oil exporting countries, the growing cost of their extraction, and global environmental problems [12]. In Germany, for example, the share of renewable energy sources (RES) in the country has grown significantly (Figures 1,2).

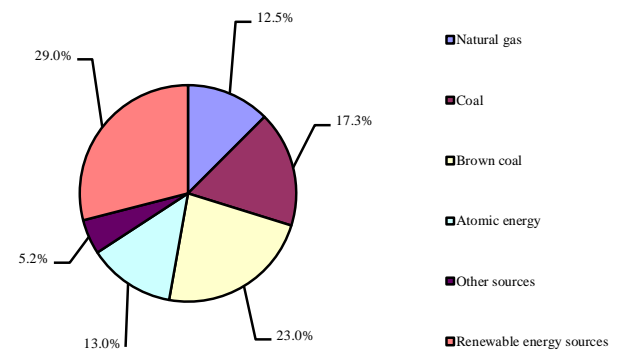

Fig. 1: Gross electric power generation in Germany in 2016, \%.
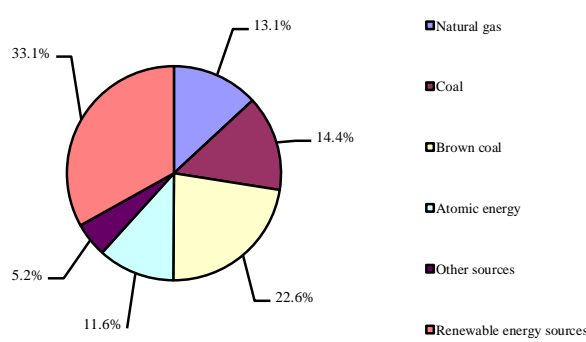

Fig. 2: Gross electric power generation in Germany in 2017, \%.

In particular, in electricity consumption it reached $36.1 \%$ (2016: $31.6 \%$ ), and in electricity generation $-33.1 \%$ (2016: $29 \%$ ). 
Totally, on the basis of renewable energy sources, record level of electricity output was generated -216.6 billion $\mathrm{kWh}$.

The output of offshore wind power plants increased most by $49 \%$ to 18 billion $\mathrm{kWh}$. Mainland wind energy increased output by $31 \%$. Solar energy grew not so much - by $4 \%$, up to almost 40 billion $\mathrm{kWh}$.

The German Renewable Energy Sources Act (EEG) states that by 2025 the share of renewable energy in the electric power consumption should be in the range of $40-45 \%$. The graph shows that their development takes place on the trajectory, which will lead to a significant excess of this goal.

In 2017 in Germany there was a significant decrease in the share of coal in electric power generation - it fell to 37\% (2016: 40.3\%) Only in 2017, six coal-fired power plants ceased their operation. The first brown coal-fired power plants were put into standby mode, and further power units operating with the use of brown coal will follow them by 2019. Decommissioning of another 14 coal-fired power plants is planned. The reason for this is the changed market conditions: there are no investments in coal-fired power plants.

By 2023, it is planned to reduce the installed capacity of coal-, oil, gas-fired power plants, and (to zero) of nuclear power plants.

At the same time, the electric power generation based on natural gas in 2017 increased, and its share - up to $13.1 \%$ (2016: 12.5\%). The natural gas consumption in Germany increased in 2017 in comparison with 2016 by slightly more than five percent - up to 985 billion kilowatt hours (2016: 936.3 billion $\mathrm{kWh}$ ). Last year, more natural gas was used at power plants to generate electric power and heat than in 2016. In addition, relatively low temperatures for several months in 2017 led to higher heat consumption. The industry also used more natural gas at its own power plants for combined electric power and heat generation.

In the US, after rapid development in 2016 and 2017, renewable energy sources displaced the nuclear sector as one of the most important sources of energy. The nuclear energy output declined by almost $3 \%$ in 2017 compared to the same period in 2016, while hydroelectric power generation increased by $9.5 \%$, and use of other renewable energy sources increased by almost $14 \%$, since all more states use cheap technology.

As we can see, the whole world has long been given preference to energy-saving technologies.

Therefore, one of the most important objectives of modern enterprises is the economical use of energy resources and increasing the efficiency of their use at all stages of production. In this connection, much attention is paid to the development of modern technologies and the implementation of organizational, technical and economic measures to improve the energy efficiency in production, as well as investments in the development of energy-saving technologies which ensure the competitiveness of enterprises and create a reliable basis for the future, while forming the image of a socially responsible enterprise.

\section{Determination of Strategic Prospects of Development of Corporate Social Responsibility in Ukraine}

In modern conditions, Ukrainian business cannot ignore the requirements of sustainable development of society. The concept of sustainable development adopted in 1992 is to meet the society's needs while preserving the opportunities for future generations and proclaims the need to balance the economic, environmental and social interests of present and future generations by creating a socially oriented economy relying on the rational use of natural resources and on environmental protection. Today, the company's image is positively influenced by its energy saving and energy efficiency activities. Which is one of the conditions for the manifestation of social responsibility, and accordingly forms a loyal public attitude towards the enterprise. The issue of assessing the impact of production enterprises on the environment is reflected in the measurement of external costs.
External costs ("Overflow costs") are the incidental costs of producing goods and services that are not borne by producers and consumers, but by the population and society as a whole without any compensation [13].

For example, in the EU countries the assessment of the damage to society caused by various modes of transport is being monitored. In addition, for the EU countries, the average annual overall and specific costs for addressing harmful effects of transport are calculated on a number of different factors (accidents, noise, air pollution, climate change, impact on nature, urban and industrial effects) (Table 2).

To ensure energy saving in enterprises, it is necessary to introduce: the integrated application of economic incentives, the identification of sources and areas of financing, the establishment of a base for the implementation of economic measures, the use of a system of state standards in determining the amount of economic benefits and the application of economic sanctions; introduction of fees for irrational use of fuel and power resources; granting subsidies, subsidies, tax, credit and other benefits to legal entities and individuals for stimulating the development, introduction and use of energy-saving technologies, relying on the existing legislative and regulatory framework and foreign expertise [1421].

Table 2: Cost allocation for addressing harmful effects [22]

\begin{tabular}{|l|c|c|}
\hline \multirow{2}{*}{ Factor } & \multicolumn{2}{c|}{$\begin{array}{l}\text { The cost value of addressing } \\
\text { harmful effects }\end{array}$} \\
\cline { 2 - 3 } & billion euro & $\%$ \\
\hline Accidents & 156 & 24 \\
\hline Noise & 46 & 7.1 \\
\hline Air pollution & 175 & 27 \\
\hline Climate change & 196 & 30.1 \\
\hline Impact on nature & 20 & 3.1 \\
\hline City effects & 10 & 1.5 \\
\hline Industrial effects & 47 & 7.2 \\
\hline Total & 650 & 100 \\
\hline
\end{tabular}

Improving energy efficiency in enterprises yield such results [23]: saving funds, increasing the competitiveness of enterprises, especially in the event of rising energy prices; increase in productivity by improving production processes associated with the method of energy use; provision of emission quotas, which reduces dependence on energy prices, reduces the company's risks, which in turn increases the value of the enterprise; reduction of emissions to the environment, which results in the improvement of the environmental status, and along with it - the image of the enterprise.

The main measures in the sphere of energy saving in enterprises that can be implemented today include [24]: the necessity of consumption accounting at the most energy-intensive production units; more efficient energy cascading; decrease in the level of reactive power consumption due to the installation of compensation facilities; increased fuel efficiency; the use of various alternative fuels; the introduction of automatic monitoring tools, the management of the distribution and use of energy supplies in production; control over the electric energy consumption for lighting, the introduction of efficient lighting systems; reduction of fuel and thermal power losses due to improved sealing of thermal equipment; repair of thermal insulation with the use of modern heat-insulating materials; introduction of modern temperature control systems; replacement of metal pipes with plastic in water, heat and gas supply systems, etc.

In general, the increase in energy efficiency leads to a reduction in energy costs, increased profitability, increased competitiveness of enterprises and, certainly, the formation of a positive image in society. And, crucially, all these measures lead to the reduction of harmful impact on the environment and the population, i.e. more environmentally friendly production.

Thus, today, the ecological component of production, specifically of products, becomes important for consumers. 


\section{Conclusions}

It is established that the company's image is heavily influenced by its activities, which leads to a reduction in society's costs of preserving life and health of the population. As well as the costs of society to eliminate the negative impact of enterprises on the atmosphere and the biosphere. This is especially true for Ukrainian enterprises, since this problem is not given proper attention in the state regulation of the economy. The concept of the company's image is improved due to the scientific justification for the introduction of social and environmental components as weighty factors affecting the corporate strategy and competitiveness.

The general trend identified in the study performed shows that in a civilized business environment, to achieve sustainable competitive advantages and consumer loyalty, it is necessary to rely on moral and social aspects. The formation of a sustainable image of an enterprise is the company's readiness to be responsible to society, namely, to take care of the environment, the health of consumers, and the observance of their consumer and civil rights. In modern conditions, every enterprise should be mindful of its responsibility to the society, and therefore, use some of its revenues, and make efforts for the benefit and improvement of the society. A significant component of the company's positive image is the company's environmental responsibility. This is an activity that benefits the environment or reduces the negative impact of business on the environment. Thus, we can justify that the corporate social and environmental responsibility is an indispensable component of the corporate strategy that will increase the competitiveness of the enterprise, enhance its reputation and form a high level of loyalty to the company's products in the minds of consumers.

\section{References}

[1] The site of the UN Global Compact, available online: https://www.unglobalcompact.org, last visit: 03.06.2018

[2] Shapoval VM (2011), Corporate social responsibility in the structure of economic management: monograph, State HEE "NGU", $356 \mathrm{p}$

[3] Gogulya OP \& Kudinov IP (2011), Corporate social responsibility, monograph, Cabinet of Ministers of Ukraine, National University of Bioresources and Natural Resources of Ukraine, Lysenko M.M., $175 \mathrm{p}$.

[4]. Novikova OF, Deych ME, Pankova OV \& others (2013), Diagnostics of the Status and Prospects for the Development of Social Responsibility in Ukraine (expert assessments), monograph, National Academy of Sciences of Ukraine, Institute of Industrial Economics, $296 \mathrm{p}$

[5] Kolot AM \& others (2012) Social Responsibility: Theory and Practice of Development, monograph, SHEE "Vadym Hetman Kyiv National Economic University", Science Park, Institute of Social Labor Relationships, KNEU, 501 p.

[6] Tsarik IM (2011) Regulatory tools for enhancing corporate socia responsibility in the system of national economy, monograph, Chernihiv State Law Institute, Social Technologies and Labor, 152 p.

[7] Antoshko TR, Krush PV \& Tyulenieva YuV (2013), Implementation of Corporate Social Responsibility at Industrial Enterprises, monograph, National technichal University of Ukraine "Kyiv Polytechnic institute", NTUU "KPI", 275 p.

[8] Dergousova AO (2014) Formation of a positive image of rail passenger traffic, Investments: practice and experience, Vol. 9, pp. 62-64.

[9] Social responsibility of business, available online: uk.wikipedia.org/wiki/, last visit: 30.04.2018

[10] Lisbon European Council 23 and 24 March 2000 presidency conclusions/, available online: http://www.europarl.europa.eu/summits/lis1_en.htm\#1, last visit: 03.06 .2018

[11] The damage from global warming over the past year reached 320 billion dollars, available online: http://www.tv21.ru/news/2018/03/30/usherb-ot-globalnogopotepleniya-za-proshlyy-god-dostig-320-mlrd-dollarov, last visit: 01.06 .2018
[12] Borovik YuT \& Yelagin YuV (2018) Energy saving and energy efficiency as factors of increasing the competitiveness of rail transport enterprises, Journal of Transport and Industry Economy, Vol. 61, pp. 103-110.

[13] Yelagin YuV \& Protsenko NO (2017), Reformation and social effects of passenger rail transportation, Journal of Transport and Industry the Economy, Vol. 58, pp. 96-102.

[14] Law of Ukraine "On Energy Saving” of 16.10.2012 No. 5463-VI. available online: http://zakon2.rada.gov.ua, last visit: 10.04.2018

15. Energy Security of Ukraine: Challenges, Opportunities, Scenarios 2020, available online: http://aeaep.com.ua/wp-content/uploads /2013/07/40.pdf, last visit: 10.05.2018

16. Energy strategy of Ukraine to 2030. , available online: http://mpe.kmu.gov.ua/minugol/doccatalog/ document?id = 260994, last visit: 10.05 .2018

[17] Updated Energy Strategy of Ukraine to 2030 , available online: http://mpe.kmu.gov.ua/fuel/control/uk/ publication / article?artid = 222035, last visit: 11.05 .2018

[18] List of basic legal acts regulating energy efficiency and energy conservation, available online: http://mpe.kmu.gov.ua/minugol/control/uk/ doccatalog/ list?currDir $=208607$, last visit: 08.05 .2018

[19] Decision of the National Security and Defense Council of Ukraine "On the state of implementation of state policy on ensuring the efficient use of fuel and energy resources", available online: http://zakon2.rada.gov.ua/laws/show/ n0023525-08, last visit: 08.04.2018

[20] Socio-economic mechanisms for stimulating energy-saving measures at the regional level, available online: http://old.niss.gov.ua/monitor/Monitor24/02.htm, last visit: 01.05.2018

[21] Energy Efficiency and its contribution to energy security and 2030 Frame work for climate and energy policy, available online: https://ec.europa.eu/energy/sites/ener/files/documents/2014_eec_co mmunication_adopted_0.pdf, last visit: 12.04.2018

[22] Charkina TYu (2013) Managing Competitiveness of Rail Passenger Transportation in the Market of Transport Services, PhD Thesis in Economics, UkrDaZT, $256 \mathrm{p}$.

[23] Maslikevich MR \& Serdyuk BM (2011) Essence of the energy efficiency assessment of the enterprise, Urgent problems of economics and management, Vol. 5, pp. 110-114.

[24] Sevastyanov RV (2013) Problems and perspectives of energy saving at industrial enterprises, Theoretical and practical aspects of economy and intellectual property: Scientific collection, SHEE "PDTU”, Ed. 1, Vol. 2, pp. 107-110. 